\title{
Arbiter jednostronnie mianowany przez stronę w arbitrażu międzynarodowym
}

DOI: http://dx.doi.org/10.12775/SIT.2013.008

Okres ostatnich kilkunastu lat to intensywny rozwój arbitrażu (sądownictwa polubownego), który uczynił z tej metody rozstrzygania sporów podstawową alternatywę dla sądownictwa powszechnego. O rozwoju tym świadczy z jednej strony stale rosnąca liczba spraw rozstrzyganych w tym postępowaniu, a $z$ drugiej istotne zwiększenie ogólnej wartości roszczeń poddanych rozstrzygnięciu sądom arbitrażowym ${ }^{1}$. Dalszy rozwój tego postępowania jest jednak uzależniony od ponownego spojrzenia na niektóre szczegółowe zagadnienia związane $z$ tym postępowaniem oraz od ich właściwego uregulowania. Jednym $z$ takich zagadnień jest pozycja arbitrów jednostronnie mianowanych przez stronę (ang. party-appointed arbitrators), gdyż jednym ze skutków rozwoju arbitrażu jest także stale powiększający się krąg osób biorących udział w tym postępowaniu. Wraz ze wzrostem popularności arbitraż przestał być swego rodzaju „klubem dżentelmenów", których działania były poddawane ocenie wąskiej

${ }^{1}$ Z udostępnionych przez stałe sądy arbitrażowe danych wynika, iż liczba spraw rozstrzyganych pod ich auspicjami, pomimo spadku w 2009 roku związanego $z$ wybuchem globalnego kryzysu gospodarczego, stale rośnie. Liczba spraw poddanych rozstrzygnięciu sądów arbitrażowych pod auspicjami CIETAC w 2011 roku wynosiła 1282 (967 spraw w 2006 roku); pod auspicjami Chamber of Arbitration of Milan - 130 (102 sprawy w 2006 roku), pod auspicjami ICC - 796 (593 sprawy w 2006 roku); pod auspicjami Instytutu Arbitrażowego Szwedzkiej Izby Handlowej - 199 (141 spraw w 2006 roku). 
grupy osób, co zapewniało przestrzeganiu przez te osoby wysokich standardów etycznych. Obecnie, w sytuacji, gdy grupa osób pełniących funkcje arbitrów w postępowaniu polubownym jest znacznie liczniejsza, właściwe ustalenie pozycji arbitrów jednostronnie mianowanych przez strony wydaję się kluczowe, w szczególności z punktu widzenia legitymizacji całego postępowania.

\section{Swoboda stron i inne cechy arbitrażu}

Sądownictwo polubowne jest jednym $\mathrm{z}$ czterech podstawowych sposobów rozwiązywania konfliktów ${ }^{2}$, którego fundamentem jest istnienie porozumienia stron co do poddania istniejącego lub mogącego dopiero powstać między nimi sporu pod rozstrzygnięcie zespołu orzekającego (zw. także trybunałem arbitrażowym), zasadniczo powoływanego zgodnie $z$ wolą stron.

Każde postępowanie polubowne zakłada istnienie sporu co najmniej dwóch stron odnośnie danego stosunku prawnego, który na mocy umowy o arbitraż (zw. także zapisem na sąd polubowny) zostaje poddany pod rozstrzygnięcie osobie bądź osobom trzecim. Charakterystyczne przy tym jest, iż rozstrzygnięcie to cechuje się ostatecznością i jest wiążące dla stron tego postępowania. Szczególną cechą arbitrażu jest również ograniczona ingerencja sądów powszechnych, zarówno w stosunku do samego postępowania, jak i jego rozstrzygnięcia.

Bez wątpienia przyczynami wzrastającej popularności arbitrażu są takie jego zalety, jak m.in. neutralność ${ }^{3}$, wykonalność orzeczeń

${ }^{2}$ L. Morawski, Główne problemy współczesnej filozofii prawa. Prawo w toku przemian, LexisNexis, Warszawa 2005, s. 213.

${ }^{3}$ Należy pamiętać, iż neutralność arbitra może być dwojako rozumiana w arbitrażu międzynarodowym. Z jednej strony może być bowiem związana z narodowością arbitra przewodniczącego, która zasadniczo powinna być odmienna od narodowości stron danego postępowania polubownego. $Z$ drugiej jednak strony, w szerszym znaczeniu, neutralność arbitra wiąże się $z$ nałożeniem na każdego $z$ arbitrów biorących udział w postępowaniu arbitrażowym obowiązku bycia i pozostania przez cały okres trwania postępowania niezależnymi i bezstronnymi. W niniejszej pracy przez pojęcie neutralności rozumie się to drugie znaczenie. 
arbitrażowych, poufność i szybkość postępowania, fachowość arbitrów oraz niższe koszty ${ }^{4}$ związane $z$ nim związane ${ }^{5}$. Co do zasady należy bowiem przyjąć, iż wybór arbitrażu jako metody rozstrzygnięcia danego sporu następuje każdorazowo po dokonaniu przez strony analizy korzyści związanych z tym postępowaniem.

Stanowiąca fundament każdego postępowania polubownego umowa o arbitraż (fr. convention d'arbitrage, niem. Schiedsvertrag, ang. arbitration agreement) jest czynnością prawną ${ }^{6}$, do której zastosowanie znajduje zasada swobody umów. Nieodłączną cechą arbitrażu jest zatem pozostawienie stronom szerokiej swobody, która przejawia się m.in. przyznaniem im prawa samodzielnego ustanawiania reguł proceduralnych ich postępowania arbitrażowego. Prawo to może być realizowane bądź przez ustanowienie swoich reguł, bądź też przez wybór regulaminu arbitrażowego któregoś ze stałych sądów arbitrażowych lub międzynarodowych instytucji arbitrażowych.

Przede wszystkim jednak zakresem swobody stron objęta jest kwestia wyboru arbitrów wchodzących w skład zespołu orzekającego, któremu zostanie poddany spór istniejący pomiędzy danymi stronami. W stosunku do trzyosobowych trybunałów arbitrażowych

${ }^{4}$ Coraz częściej wskazuje się jednak, iż arbitraż przestał być uważany za postępowanie tańsze od postępowania sądowego. W rzeczywistości koszty związane $z$ postępowaniem arbitrażowym niejednokrotnie mogą być podobne lub nawet wyższe od tych związanych $z$ postępowaniem sądowym.

${ }^{5}$ Należy pamiętać, iż katalog zalet i korzyści arbitrażu może się różnić w zależności od okoliczności i rodzaju danego postępowania arbitrażowego.

${ }^{6}$ Odnośnie do funkcjonujących w doktrynie i judykaturze poglądów co do charakteru prawnego umowy o arbitraż zobacz: Ł. Błaszczak, M. Ludwik, Sadownictwo polubowne (arbitraż), C.H. Beck, Warszawa 2007, s. 83-87; K. Piasecki, Kodeks postępowania cywilnego, t. 3: Komentarz do artykułów 1096-1217 KPC oraz aktów prawych UE regulujacych międzynarodowe postępowanie cywilne, red. K. Piasecki, Warszawa 2007, s. 255-258; T. Ereciński, Kodeks postępowania cywilnego. Komentarz, cz. 4: Przepisy z zakresu międzynarodowego postępowania cywilnego, cz. 5: Sąd polubowny (arbitrażowy), Warszawa 2006, s. 367; J. Skoczylas, Charakter prawny zapisu na sad polubowny a autonomia regulacji prawnej arbitrażu (po nowelizacji z 2005 r.), w: Księga pamiątkowa 60-lecia Sądu Arbitrażowego przy Krajowej Izbie Gospodarczej w Warszawie, red. J. Okolski, Warszawa 2010. 
prawo wyboru własnego arbitra przyjęło się przy tym uznawać za fundamentalne ${ }^{7}$.

Należy jednak w tym miejscu nadmienić, iż umowa o arbitraż to coś więcej aniżeli zwykłe porozumienie, którego skutkiem jest umożliwienie stronie pozwanej uchylenia się od rozstrzygnięcia sporu przez sąd powszechny przez podniesienie zarzutu związania stron zapisem na sąd polubowny. Umowa ta niejednokrotnie zawiera szczegółowe i skomplikowane postanowienia regulujące sposób rozwiązania konkretnego sporu, często przy tym ustanawiając złożone i wieloetapowe procedury, stanowiące rezultat długich negocjacji między stronami ${ }^{8}$.

\section{Międzynarodowy charakter arbitrażu}

Arbitraż międzynarodowy jest szczególnym rodzajem postępowania polubownego, zakładającym istnienie elementu obcego, niezwiązanego $z$ obszarem prawnym państwa, w którym arbitraż ma swoje miejsce ${ }^{9}$. $Z$ arbitrażem międzynarodowym wiążą się dwie cechy charakterystyczne. Po pierwsze, ustalenie elementu obcego w da-

7 Zob. wyrok francuskiego Court de Cassation z dnia 7 stycznia 1992 r. w sprawie Siemens AG \& BKMI Industrienlagen Gmbh v. Dutco Construction Co., „XVIII Yearbook Commercial Arbitration” 1993, s. 140-142.

8 T. Wardyński, Kilka uwag o istocie arbitrażu, w: Księga pamiątkowa 60-lecia Sądu Arbitrażowego, s. 111.

${ }_{9}$ Pojęcie arbitrażu międzynarodowego nie jest jednak tożsame $z$ pojęciem arbitrażu zagranicznego. W doktrynie przyjmuje się, zgodnie z teorią terytorialną, która wiąże arbitraż z systemem prawnym państwa, w jakim się on toczy albo w jakim został wydany wyrok arbitrażowy, że arbitrażem zagranicznym jest każde postępowanie, które ma swoje miejsce w innym państwie. Wskazania przy tym wymaga, iż to zagraniczne postępowania arbitrażowe są przedmiotem Konwencji nowojorskiej w sprawie uznawania i wykonywania zagranicznych orzeczeń arbitrażowych z 1958 r., powszechnie uważanej za fundament współczesnego arbitrażu międzynarodowego. Konwencja ta normuje uznawanie i wykonywanie orzeczeń arbitrażowych, które wskutek sporów między osobami fizycznymi lub prawnymi zostały wydane na obszarze państwa innego niż to, w którym żąda się uznania i wykonania tych orzeczeń (art. 1 Konwencji). Zob. A.W. Wiśniewski, Międzynarodowy arbitraż handlowy w Polsce. Status prawny arbitrażu i arbitrów, Warszawa 2011, s. 137 i n. 
nym postępowaniu nie wpływa na ustalenie właściwości systemu prawnego normującego te postępowanie. Po drugie natomiast, jego wyróżnienie możliwe jest jedynie w stosunku do postępowań wcześniej już zakwalifikowanych jako krajowe, co wiąże się $z$ faktem, iż każde postępowanie arbitrażowe, niezależnie od krajowego czy międzynarodowego charakteru, zawsze jest połączone $z$ prawem określonego państwa, stanowiącym lex arbitri $^{10}$. Trafnie przy tym wskazuje się w doktrynie, iż pomiędzy arbitrażem międzynarodowym a krajowym nie ma zasadniczych różnic ustrojowych, z czym wiąże się również fakt, iż wiele krajowych regulacji arbitrażowych traktuje oba te rodzaje postępowań w sposób jednolity ${ }^{11}$.

W zależności od przyjętej w danym systemie prawnym koncepcji, międzynarodowy charakter arbitrażu będzie wynikał bądź z odmiennej przynależności prawnej stron (tzw. podejście podmiotowe lub subiektywne, ang. subcjective criterion) ${ }^{12}$, bądź też z międzynarodowego charakteru sporu będącego przedmiotem toczącego się postępowania (tzw. podejście przedmiotowe lub obiektywne, ang. objective criterion) ${ }^{13}$.

10 Zob. ibidem, s. 141-142.

${ }^{11}$ Ł. Błaszczak, M. Ludwik, op.cit., s. 55.

12 Przykładem zastosowania podejścia podmiotowego jest prawo szwajcarskie, które w art. 176 ustawy o prawie międzynarodowym prywatnym uznaje arbitraż za międzynarodowy, jeżeli w czasie zawierania umowy o arbitraż przynajmniej jedna ze stron nie miała miejsca zamieszkania lub stałego pobytu w Szwajcarii, oraz Konwencja europejska o międzynarodowym arbitrażu handlowym, sporządzona w Genewie dnia 21 kwietnia 1961 r., która znajduje zastosowanie do „umów o arbitraż zawieranych w celu rozstrzygania sporów wynikających przy dokonywaniu transakcji handlu międzynarodowego między osobami fizycznymi, jak i prawnymi, które w chwili zawierania takich umów mają stałe miejsce zamieszkania bądź swoją siedzibę w różnych umawiających się państwach”. Zob. Arbitraż handlowy - System Prawa Handlowego, Arbitraż handlowy, t. 8, red. A. Szumański, C.H. Beck, Warszawa 2010, s. 30.

13 Podejście przedmiotowe jest wyraźnie widoczne w prawie francuskim. Zgodnie $z$ przepisem art. 1482 francuskiego kodeksu postępowania cywilnego arbitraż międzynarodowy jest postępowaniem, które dotyczy interesów z zakresu handlu międzynarodowego, niezależnie od innych czynników. Zob. P. Fouchard, E. Gailard, E. Goldman, B. Savage, Fouchard, Gailard, Goldman on International Commercial Arbitration, "Kluwer Law International” 1999, s. 55-61. 
Wydaje się, iż współcześnie najszerszą definicję arbitrażu międzynarodowego zawiera Ustawa modelowa UNCITRAL ${ }^{14}$ (zw. dalej również Ustawą modelową), z zastrzeżeniem, iż zakres jej zastosowania jest ograniczony do międzynarodowego arbitrażu handlowego. Zgodnie $z$ przepisem art. 1 ust. 2 Ustawy modelowej UNCITRAL, arbitraż ma międzynarodowy charakter, jeżeli: 1) strony mają swoje siedziby handlowe w różnych państwach; 2) miejsce arbitrażu określone w umowie o arbitraż lub na jej podstawie, miejsce wykonania istotnej części zobowiązań $z$ danego stosunku albo miejsce, $z$ którym najściślej jest związany przedmiot sporu, znajduje się w innym państwie niż to, w którym obie strony mają swoje siedziby handlowe; 3) strony wyraźnie uzgodniły, że przedmiot umowy o arbitraż jest związany $z$ więcej niż jednym państwem. Przyjęta na gruncie Ustawy modelowej definicja stanowi zatem kompromis pomiędzy podejściem subiektywnym a obiektywnym.

Udział w danym postępowaniu co najmniej dwóch podmiotów o odmiennej przynależności prawnej oznacza, iż będziemy mieli co do zasady do czynienia $z$ konfrontacją poglądów charakterystycznych dla co najmniej dwóch różnych systemów prawnych. Co więcej, skorzystanie przez strony z przysługującego im uprawnienia wyboru własnego arbitra skutkuje na ogół powstaniem międzynarodowego zespołu orzekającego, w którym będą zasiadać przedstawiciele odmiennych system prawnych, zaznajomieni ze zwyczajami charakterystycznymi dla danego systemu.

\section{Zespoły orzekające i arbitrzy jednostronnie mianowani przez strony}

W odróżnieniu od postępowania przed sądem powszechnym w arbitrażu konieczne jest każdorazowe formowanie się sądu arbitrażowego, rozumianego jako trybunał arbitrażowy, składający się $\mathrm{z}$ jednego lub więcej arbitrów. Jest to przy tym jeden $z$ najważniej-

\footnotetext{
14 Ustawa modelowa UNCITRAL była wynikiem prac Komisji Międzynarodowego Prawa Handlowego ONZ. Przyjęta przez Zgromadzenie Ogólne ONZ na mocy rezolucji nr 40/72 z 1985 r.
} 
szych i najtrudniejszych etapów całego postępowania polubownego, gdyż decyzja odnośnie do wyboru danego arbitra ma bezpośredni wpływ na poziom rzetelności i fachowości nie tylko orzeczenia rozstrzygającego spór, ale i całego postępowania. W doktrynie prawniczej trafnie się bowiem przyjmuje, iż arbitraż może być jedynie tak dobry, jak dobrzy są arbitrzy tworzący trybunał arbitrażowy ${ }^{15}$.

Na etapie konstytuowania się zespołu orzekającego decydujące znaczenie należy przypisać stosownemu porozumieniu stron, na mocy którego mogą one zdecydować nie tylko o liczbie i sposobie mianowania arbitrów mających zostać zaangażowanych w postępowaniu, lecz także o szeregu innych, nieraz szczegółowych kwestii.

Współcześnie dwoma najpopularniejszymi modelami wśród trybunałów arbitrażowych są składy jedno- (ang. sole arbitrator) lub trzyosobowe (ang. three member tribunal, tripartite tribunal ${ }^{16}$. Jakkolwiek trybunał jednoosobowy cechuje się szeregiem zalet, podstawową wartością trybunału trzyosobowego, decydującą o przewadze tego modelu, jest fakt, iż umożliwia efektywne przedyskutowanie okoliczności towarzyszących danej sprawie, przy jednoczesnym ograniczeniu niedogodności związanych $z$ większą liczbą arbitrów, takich jak trudności z zorganizowaniem wspólnego spotkania lub znaczne zwiększenie kosztów postępowania. W literaturze wskazuje się ponadto, iż za trzyosobowymi zespołami orzekającymi przemawia również fakt, iż orzeczenie takiego zespołu jest dla strony przegrywającej sprawę łatwiejsze do zaakceptowania ${ }^{17}$.

Trzyosobowe trybunały arbitrażowe mogą być powoływane na kilka sposobów. Najpopularniejszy zakłada, iż każda ze stron sporu jednostronnie mianuje wybranych przez siebie arbitrów ${ }^{18}$, którzy

15 J.F. Lalive, Mélanges en l'honneur de Nicolas Valticos in Droit et Justice (Editions Pédone, 1989), s. 289, cyt. za: A. Redfern, M. Hunter, N. Blackaby, C. Partasides, Law and Practice of International Commercial Arbitration, "Kluwer Law International" 2004, s. 10.

${ }^{16}$ Zob. np. art. 10 pkt 2 Ustawy modelowej UNCITRAL, art. 1169 § 2 k.p.c., art. 12 Regulaminu Instytutu Arbitrażowego Sztokholmskiej Izby Handlowej.

17 R. Mosk, The Role of Party-Appointed Arbitrators in International Arbitration: The Experience of the Iran - United States Claims Tribunal, "Transnational Law" 1998, nr 1, s. 253.

${ }^{18} \mathrm{~W}$ polskiej doktrynie prawniczej funkcjonuje również pojęcie „arbitrów bocznych", które jednak nie jest tożsame $z$ pojęciem arbitrów jednostronnie 
następnie łącznie dokonują wyboru spoza swego grona trzeciego arbitra, sprawującego funkcję przewodniczącego trybunału (ang. chairman, president of the tribunal ${ }^{19}$. Bardziej skomplikowane sposoby zakładają natomiast prawo kontroli danej instytucji arbitrażowej nad wyborem stron ${ }^{20}$ lub nawet zastrzeżenie na rzecz takiej instytucji prawa powołania arbitra przewodniczącego (a nawet arbitrów „bocznych”) ${ }^{21}$.

Należy podkreślić, iż arbitrzy jednostronnie mianowani przez strony zasadniczo pełnią taką samą rolę w postępowaniu, co arbitrzy mianowani w inny sposób. Podstawowym zadaniem każdego arbitra, bez względu na sposób jego mianowania, jest bowiem rozstrzygnięcie przedłożonego mu sporu. W tych okolicznościach nie może zatem dziwić, iż zdecydowana większość regulacji arbitrażowych nie dokonuje rozróżnienia na party-appointed arbitrators i pozostałych arbitrów $^{22}$. Natomiast wyodrębnienie kategorii arbitrów jednostronnie mianowanych w ogólnej grupie arbitrów zostało dokonane przez doktrynę prawniczą oraz część kodeksów etycznych ${ }^{23}$.

Bez wątpienia w arbitrażu międzynarodowym, w którym każda ze stron zasadniczo reprezentuje inny system prawny, wybór własnego arbitra ma niebagatelne znaczenie. Co więcej, wydaje się, iż znaczenie to rośnie wraz z wzrostem wartości przedmiotu sporu. Arbitrzy

mianowanych przez strony, gdyż arbitrem bocznym jest zasadniczo każdy arbiter niebędący przewodniczącym, niezależnie, czy zostaje on mianowany (ew. powołany) przez stronę, stały sąd polubowny czy inną instytucję arbitrażową.

19 Powoływanie przez arbitrów „bocznych” przewodniczącego spoza swego grona stanowi przy tym o przewadze zespołów trzyosobowych nad składami dwuosobowymi. Jakkolwiek bowiem drugi ze wskazanych trybunałów także umożliwia przedyskutowanie danej sprawy, to jednak w przypadku trzyosobowych zespołów orzekających przewodniczący dysponuje głosem decydującym i może pogodzić arbitrów „bocznych”.

${ }^{20} \mathrm{~W}$ takim przypadku prawo stron wyboru arbitra zostaje w rzeczywistości ograniczone do prawa mianowania arbitra, które podlega następnie procedurze zatwierdzającej przeprowadzanej każdorazowo przez daną instytucję arbitrażową.

${ }^{21}$ Zob. regulaminy ICC International Court of Arbitration lub London Court of International Arbitration.

22 P. Fouchard, E. Gailard, B. Goldman, op.cit., s. 557.

${ }^{23}$ Zob. np. Kodeks etyczny Mediolańskiej Izby Arbitrażowej (ang. Chamber of Arbitration of Milan). 
jednostronnie mianowani przez strony bardzo często wnoszą do przedmiotowego postępowania niezbędną wiedzę i doświadczenie, a także na ogół bardzo dobrze znają system prawny i zwyczaje właściwe dla strony ich powołującej ${ }^{24}$. Zdarza się jednak, iż strony postrzegają wybranych przez siebie arbitrów jako osoby, których obowiązkiem jest sprzyjanie, a nawet pomaganie ${ }^{25}$ powołującej ich stronie $^{26}$. Stanowisko takie koniecznością czyni jednak ustalenie rzeczywiście odgrywanej roli przez arbitrów jednostronnie mianowanych przez strony w międzynarodowym postępowaniu arbitrażowym, z czym nierozerwalnie wiąże się kwestia neutralności tych arbitrów.

\section{Rola arbitrów jednostronnie mianowanych przez strony w arbitrażu międzynarodowym}

W literaturze wskazuje się na trzy przyczyny, dla których strony decydują się na party-appointed arbitrators: 1) strony nie do końca rozumieją, czym jest arbitraż, i wybór własnego arbitra ma na celu wzmocnienie ich poczucia bezpieczeństwa; 2) strony obawiają się nieprzewidywalnego neutralnego arbitra i wolą wybrać „swoich” arbitrów, którzy ewentualnie przegłosują arbitra przewodniczącego; 3) strony, powołując „swojego” arbitra, uważają, iż mają przez to większy wpływ na prace zespołu orzekającego, a co za tym idzie na cały przebieg postępowania arbitrażowego ${ }^{27}$.

24 R. Mosk, op.cit., s. 253.

${ }^{25}$ Pomoc arbitra jednostronnie mianowanego przez stronę może przejawiać się tutaj np. bądź przez informowanie danej strony o przebiegu narady zespołu orzekającego, bądź też przekonując pozostałych arbitrów do stanowiska prezentowanego przez tą stronę. Zob.: R. Taichert, Why not provide for neutral party-appointed arbitrators?, “Dispute Resolution Journal” 2002/2003, $\mathrm{Nr} 57 / 4$, s. 22; J. Redmond, UK - Party-appointed arbitrators: Hired Guns or Loose Cannons?, artykuł opublikowany w dniu 14 lutego 2008 roku można znaleźć na portalu www.mondaq.com (dostęp: 10.01.2013).

${ }^{26}$ J. Redmond, op.cit.

${ }^{27}$ S. Lieberman, Something's Rotten in the State of Party-Appointed Arbitration: Healing ADR's Black Eye that is "Nonneutral Neutrals", "Cardozo Journal of Conflict Resolution” 2004, nr 5/2, s. 215. 
W arbitrażu międzynarodowym, charakteryzującym się udziałem stron o odmiennej przynależności prawnej i pochodzących zasadniczo $\mathrm{z}$ odmiennych systemów prawnych, powody stojące za wyborem przez strony „swoich” arbitrów są nieco inne. W takim postępowaniu party-appointed arbitrators pełnią bowiem rolę swego rodzaju „tłumaczy”. Ich zadaniem jest wyjaśnienie zespołowi orzekającemu właściwego dla strony go powołującej systemu prawnego i panujących w nim zwyczajów ${ }^{28}$. W ten sposób zespół orzekający zmienia się w sui generis platformę wymiany poglądów, co ma niebagatelne znaczenie dla jakości i prawidłowości rozstrzygnięcia. Party-appointed arbitrators ma zatem zapewnić, że stanowisko i argumenty przedstawione przez powołującą go stronę będą właściwie zrozumiane oraz rozważone przez pozostałych członków trybunału arbitrażowego.

Skutkiem zaangażowania przez strony „swoich” arbitrów jest zniwelowanie ryzyka powstania nieporozumień i pomyłek w toku całego postępowania, które mogłyby wpłynąć na treść orzeczenia arbitrażowego. Tym samym party-appointed arbitrators pozwalają zniwelować groźbę wydania przez zespół orzekający niesprawiedliwego orzeczenia, którego uchylenie na ogół wymaga wykazania zaistnienia określonych, rygorystycznych przesłanek.

Arbitrzy jednostronnie mianowani przez stronę pełnią również w arbitrażu międzynarodowym funkcję swego rodzaju „mężów zaufania”. Obecność w zespole orzekającym osoby wywodzącej się z takiego samego lub podobnego systemu prawnego co strona go powołująca, podzielającej jej poglądy prawne i znającej charakterystyczne dla tej strony zwyczaje wzbudza zaufanie stron zarówno do samego postępowania, jak i do kończącego go rozstrzygnięcia. Obecność party-appointed arbitrators w trybunale arbitrażowym oznacza także, iż powołujące go strony będą wysłuchane przez pozostałych arbitrów.

Rola sprawowana przez party-appointed arbitrators zakłada istnienie pewnego związku pomiędzy stroną powołującą takiego arbitra a samym arbitrem. Stopień intensywności takiego związku może i niejednokrotnie budzi jednak pewne wątpliwości. Jak zostało bo-

28 Ibidem. 
wiem już wcześniej wskazane, zdarza się, iż strona postępowania arbitrażowego widzi w „swoim” arbitrze osobę, której - bardziej lub mniej formalnym ${ }^{29}$ - obowiązkiem jest popierać jej stanowisko, bez względu na okoliczności towarzyszące danej sprawie i sytuacji prawnej z nimi związanej. Gdyby uznać takie stanowisko, arbitrzy ci bezsprzecznie nie mogliby zostać uznani za neutralnych w pełni znaczenia tego pojęcia.

Obecnie wydaje się dominować przeciwny pogląd, zgodnie $z$ którym każdy arbiter - w tym także jednostronnie mianowany przez stronę - musi zachować odpowiedni „dystans” w stosunku do strony go powołującej i podejmować decyzje oparte wyłącznie na stanie faktycznym oraz prawnym przedstawionej mu sprawy. Nie jest przy tym zakazane mianowanie arbitra, który podziela poglądy strony go mianującej, o ile arbiter taki opowie się ostatecznie za stroną, która posiada silniejsze argumenty ${ }^{30}$. Jest bowiem naturalne, iż decydując się na udział w postępowaniu party-appointed arbitrators, strony zawsze będą szukały kogoś, kto będzie w możliwie najwyższym stopniu podzielał ich stanowisko, ale wobec którego nie będzie możliwe postawienie zarzutu stronniczości ${ }^{31}$. Każdy $z$ arbitrów wchodzących w skład zespołu orzekającego musi być zatem neutralny.

\section{Neutralność arbitrów jednostronnie mianowanych przez strony}

Koncepcja nieneutralności party-appointed arbitrators jest obecnie przede wszystkim popularna w Stanach Zjednoczonych, co ma związek $\mathrm{z}$ jednej strony $\mathrm{z}$ silnie kontraktowymi podstawami tamtejszego systemu sądownictwa polubownego, umożliwiającymi stronom ustanowienie niemal dowolnych reguł ich postępowania

${ }^{29}$ Zob. R. Taichert, op.cit., s. 22; H. Smit, The pernicious institution of party-appointed arbitrator, "Columbia FDI Perspectives" 14 lutego 2010, nr 33.

${ }^{30}$ D. Bishop, L. Reed, Practical guidelines for interviewing, selecting and challenging party-appointed arbitrators in international commercial arbitration, “Arbitration International” 1998, nr 14, s. 395.

${ }^{31}$ M. Hunter, Ethics of the International Arbitrator, "Arbitration" 1987, nr 53, s. 219-223. 
arbitrażowego, $z$ drugiej natomiast $z$ genezą tego systemu, którego początki ściśle łączą się $z$ arbitrażem pracowniczym i ubezpieczeniowym, w których prawo wyboru własnego arbitra stanowi kwestię fundamentalną $z$ uwagi na duże zantagonizowanie stron ${ }^{32}$.

U podstaw tej koncepcji leży założenie, iż arbitrzy jednostronnie mianowani przez strony są nie tylko w jakiś sposób związani $z$ powołującą ich stroną, ale przede wszystkim, iż arbitrzy ci powinni być przychylni powołującej go stronie. W ten sposób jedynym rzeczywiście neutralnym i bezstronnym arbitrem w zespole orzekającym jest jego przewodniczący. Prowadzi to do powstania „arbitrażu w samym arbitrażu”33, gdzie arbiter pełniący funkcję przewodniczącego oprócz sporu istniejącego pomiędzy stronami - rozstrzyga również spór pomiędzy arbitrami jednostronnie mianowanymi. Akceptacja braku neutralności part-appointed arbitrators prowadzi m.in. do zezwolenia na gruncie systemu amerykańskiego na bezpośrednią komunikację pomiędzy takim arbitrem a stroną go powołującą.

Brak neutralności arbitrów jednostronnie mianowanych znalazł potwierdzenie w orzecznictwie amerykańskim. Klasycznym orzeczeniem jest tutaj wyrok w sprawie Astoria Medical Group v. Health Insurance Plan of Greater New York ${ }^{34}$, w którym został wyrażony jednoznaczny pogląd, iż ,arbiter jednostronnie mianowany przez stronę nie jest i nie może być uważany za neutralnego”. Podobne stanowisko zostało zaprezentowane w sprawie Society for Goodwill to Retarted Children v. Carey ${ }^{35}$. O krok dalej poszedł inny sąd amerykański w sprawie Sunkist Soft Drinks, Inc. v. Sunkist Growers, Inc. ${ }^{36}$, gdzie stwierdził, iż party-appointed arbitrator nie tylko może, ale i powinien być przychylny wobec strony go powołującej. Warto

32 J. Redmond, op.cit.

33 T. Carbonneau, The Exercise Of Contract Freedom In The Making Of Arbitration Agreement, "Vanderbilt Journal of Transnational Law" 2003, nr 36, s. 1189 , cyt. za: C. Rogers, Ethics in International Arbitration, "Bocconi University Legal Studies Research Paper Series” 2008, nr 08-01, s. 90.

${ }^{34}$ Wyrok New York Court of Appeals z 29 marca 1962 roku, 182 N.E. 2d 85 (1962 rok).

35 „Nikt nie oczekuje od takich (tj. jednostronnie mianowanych przez strony - J. K.) arbitrów neutralności”.

${ }^{36}$ Sunkist Soft Drinks, Inc. v. Sunkist Growers, Inc., the Eleventh Circuit Court, “The Federal Reporter Third Series” 1993, nr 10, s. 753: “a party-appointed 
również zwrócić uwagę na orzeczenie w sprawie Merit Ins. v. Leatherby Ins. ${ }^{37}$, w którym arbitrzy jednostronnie mianowani wyraźnie są nazywani reprezentantami stron ich powołujących ${ }^{38}$.

Współcześnie wydaje się dominować jednak zupełnie odmienny pogląd, zakładający neutralność nie tylko przewodniczącego zespołu orzekającego, ale wszystkich arbitrów biorących udział w postępowaniu arbitrażowym. Zdobywa on coraz większą popularność również w Stanach Zjednoczonych ${ }^{39}$. Zgodnie $z$ tym poglądem każdy $z$ arbitrów, bez względu na sposób, w jaki został mianowany, musi spełniać wymóg neutralności będący kluczowym gwarantem niezależnego i bezstronnego rozstrzygnięcia przedłożonego danym arbitrom sporu. Niespełnienie zaś tego wymogu jest uznawane za wadę proceduralną postępowania i prowadzi zasadniczo do nieważności wydanego w sprawie orzeczenia arbitrażowego ${ }^{40}$.

Wydaje się, iż powszechne uznanie tego drugiego poglądu jest odpowiedzią doktryny i praktyki na burzliwy rozwój arbitrażu oraz próbą zagwarantowania wiarygodności całego sądownictwa polubownego, niezbędną do dalszego rozwoju tej instytucji. Jednocześnie zwycięstwo tego poglądu oznacza przyjęcie teorii quasi-sędziowskiej roli sprawowanej przez arbitrów za podstawę współczesnego

arbitrator is permitted, and should be expected, to be predisposed toward the nominating party's case".

${ }^{37}$ Merit Insurance Company $v$. Leatherby Insurance Company $a / k / a$ Western Employers Insurance Company, United States Court of Appeals Seventh Circuit, “The Federal Reported Second Series” 1983, nr 714, s. 673.

38 Należy jednak podkreślić, iż sądy amerykańskie sukcesywnie odmawiały uznania prawnego obowiązku po stronie arbitrów dbania o interesy powołującej ich strony. Zob. wyrok w sprawie Sphere Drake Insurance Ltd. v. All American Life Insurance Co., "The Federal Reporter Third Series” 2002, nr 307, s. 617-620.

${ }^{39}$ Zob. wyrok w sprawie Metropolitan Property \& Casualty Insurance Co. v. J.C. Penney Co., cyt. za: O. Byrne, A New Code Of Ethics for Commercial Arbitrators: The Neutrality of Party-Appointed Arbitrators on a Tripartite Panel, "Fordham Urban Law Journal" 2002, nr 30/6, s. 1815 i n., a także znowelizowany w 2004 roku Kodeks etyki arbitrów w sporach handlowych, stworzony wspólnie przez AAA i ABA.

${ }^{40}$ Zob. H. de Vries, International Commercial Arbitration: A Transnational View, "Journal of International Arbitration" 1984, z. 1, nr 7, s. 13, cyt. za: R. Mosk, op.cit., s. 260. 
arbitrażu. Uznanie poglądu o neutralności party-appointed arbitrators wiąże się bowiem nierozerwalnie $z$ nałożeniem na wszystkich arbitrów zaangażowanych w postępowaniu wysokich standardów etycznych, właściwych sędziemu.

Dowodem przemawiającym za dominacją w środowisku arbitrażu międzynarodowego drugiego $z$ wymienionych poglądów jest brzmienie Ustawy modelowej UNCITRAL i zdecydowanej większości krajowych regulacji arbitrażowych, wzorowanych na tej ustawie, a także Wytycznych IBA dotyczące konfliktów interesów w międzynarodowym arbitrażu z 2004 r. (ang. International Bar Association Gudielines on Conflicts of Interest International Arbitration), które stanowią obecnie najpopularniejszy kodeks etyczny w arbitrażu międzynarodowym.

Warto w tym miejscu zasygnalizować, iż dążąc do zapewnienia rzeczywistej neutralności arbitrów jednostronnie mianowanych przez strony część, doktryny proponuje zmianę w sposobie ich powoływania. Zgodnie $z$ sugerowanymi zmianami party-appointed arbitrators byliby powoływani w sposób niejako anonimowy, tak aby osoby mianowane na arbitra nie wiedziały, która ze stron danego postępowania ich powołała ${ }^{41}$. Postulat ten opiera się na przekonaniu, iż arbiter posiadający wiedzę co do strony, która go powołała, może czuć się zobligowany, w mniejszym bądź większym zakresie, do sprzyjania powołującej go stronie.

\section{Funkcja pełniona przez arbitra w postępowaniu arbitrażowym}

Za poglądem nakładającym na wszystkich arbitrów, w tym także tych jednostronnie mianowanych przez strony, wymogu bycia neutralnymi i spełnienia wysokich standardów etycznych przemawia przede wszystkim pełniona przez arbitrów funkcja. W myśl koncepcji zakładającej stronniczość party-appointed arbitrators, arbitrom tym odmawia się przyznania statusu quasi-sędziów na rzecz uznania ich za swego rodzaju reprezentantów stron, którzy mają - przez popiera-

${ }^{41}$ R. Taichert, op.cit., s. 22. 
nie argumentów danej strony prowadzącego nawet do prowadzenia postępowania $\mathrm{w}$ taki sposób, aby uwydatnić silne argumenty tej strony $^{42}$ - zadbać o interes strony ich mianującej.

W doktrynie prawniczej za arbitra uznaje się osobę powołaną przez strony do rozstrzygnięcia sporu, który zgodnie $z$ umową o arbitraż należy do właściwości sądu arbitrażowego ${ }^{43}$. Jej zadaniem jest dokonanie wyczerpującej analizy stanu faktycznego i prawnego przedłożonego mu sporu oraz wydanie obiektywnego i rzetelnego wyroku. Bezsprzeczne jest zatem, iż w sprawowanej przez siebie funkcji arbiter w rzeczywistości bardziej przypomina sędziego sądu powszechnego aniżeli reprezentanta danej strony. Arbiter bowiem, podobnie jak sędzia sądu powszechnego, w swoich rozważaniach opiera się na dowodach i argumentacji przedstawionych przez każdą ze stron sporu i kończy tenże spór przez wydanie wiążącego strony orzeczenia opartego na ustalonych okolicznościach faktycznych sprawy, popartego argumentacją prawną i będącego wynikiem niezależnej oceny faktów przez pryzmat posiadanego doświadczenia ${ }^{44}$.

Ponadto, przeciwko uznaniu arbitra za reprezentanta danej strony przemawiają dwie okoliczności. Po pierwsze, nie sposób uznać, aby w jednej osobie koncentrowały się dwie, zasadniczo przeciwstawne, funkcje sędziego i reprezentanta strony ${ }^{45}$. Po drugie, nie można nie zauważyć, iż arbiter nie jest członkiem zespołu prawnego reprezentującego daną stronę, ale wchodzi w skład trybunału orzekającego ${ }^{46}$. Co więcej, uznanie arbitra jednostronnie mianowanego za reprezentanta danej strony, którego zadania byłyby analogiczne do tych, jakie są charakterystyczne dla profesjonalnych pełnomocników, rodziłoby pytania o zasadność zatrudniania przez

${ }^{42}$ Tego rodzaju postępowanie może się przejawiać m.in. w zadawaniu pytań świadkom, które nie służą wyczerpującemu ustaleniu stanu faktycznego sprawy, ile raczej zmierzają do potwierdzenia stanowiska strony powołującej takiego arbitra.

43 A.W. Wiśniewski, op.cit., s. 492.

${ }^{44}$ Zob. S. Franck, The Role of International Arbitrators, "ILSA Journal of International \& Comparative Law" 2006.

45 S. Lieberman, op.cit., s. 241 i n.

${ }^{46}$ A. Lowenfeld, The Party-Appointed Arbitrator in International Controversies: Some Reflections, “Texas International Law Journal” 1995, nr 30, s. 65 i n. 
strony nieraz dość licznych zespołów fachowych pełnomocników. Do przedstawienia stanowiska danej strony zespołowi orzekającemu wystarczyłby bowiem w takim przypadku jedynie mianowany przez nią party-appointed arbitrator.

\section{Niezależność i bezstronność arbitra w arbitrażu międzynarodowym}

Neutralność wszystkich arbitrów zaangażowanych w postępowaniu arbitrażowym jest wymuszana przez nałożenie na tych arbitrów obowiązku bycia i pozostania przez cały okres trwania postępowania niezależnymi i bezstronnymi. Co do zasady obowiązek ten nakładają wszystkie akty normujące postępowanie arbitrażowe, od Ustawy modelowej UNCITRAL i ustawodawstwo krajowe, przez regulaminy arbitrażowe stałych sądów polubownych, po Wytyczne IBA dotyczące konfliktu interesów w arbitrażu międzynarodowym. Przy czym we wszystkich tych aktach brak jest podziału na arbitrów jednostronnie mianowanych i pozostałych arbitrów, co oznacza, iż traktują one kategorię arbitrów jako grupę jednolitą. Wyraźnym przykładem zwycięstwa poglądu o neutralności wszystkich arbitrów jest tutaj Regulamin arbitrażowy Londyńskiego Sądu Arbitrażu Międzynarodowego (ang. Arbitration Rules of London Court of International Arbitration, LCIA), którego art. 5.2 stanowi, iż wszyscy arbitrzy prowadzący postępowanie arbitrażowe według tego Regulaminu muszą być i pozostać przez cały okres trwania postępowania bezstronni i niezależni od którejkolwiek ze stron, i nie mogą działać jako reprezentanci żadnej ze stron.

Doktryna prawnicza definiuje niezależność arbitra jako tego rodzaju sytuację, faktyczną lub prawną, w której brak jest związku między arbitrem a którąkolwiek ze stron postępowania cechującego się zawodowym lub osobistym powiązaniem arbitra i strony albo istnieniem między nimi stosunku rodzinnego, biznesowego czy emocjonalnego ${ }^{47}$. Istotne jednak jest, iż nie chodzi tutaj o każdy tego

47 L. Trakman, The impartiality and independence of arbitrators reconsidered, “International Arbitration Law Review” 2007, nr 10, s. 1004. Zob. również 
rodzaju związek, ale wyłącznie o taki, który może zostać obiektywnie zweryfikowany ${ }^{48}$.

Przez bezstronność rozumie się z kolei pewien stan umysłu. $\mathrm{Z}$ tego względu jest to zjawisko dużo bardziej abstrakcyjne i subiektywne aniżeli niezależność. Bezstronność oznacza, iż po stronie arbitra zachodzi stan pełnego obiektywizmu w rozstrzyganiu poddanego mu sporu i oparcia swojego orzeczenia na rzetelnej oraz sprawiedliwej analizie zebranego w sprawie materiału dowodowego. By można było mówić o bezstronności arbitra, dokonywana przez niego analiza stanu faktycznego i prawnego musi być wolna od jakichkolwiek uprzedzeń wobec którejkolwiek ze stron lub przedmiotu sporu. Innymi słowy, musi ona pomijać wszelkie pozamerytoryczne okoliczności danej sprawy.

Obowiązek zachowania przez arbitrów niezależności i bezstronności jest w swej istocie dość ogólny i wymaga ustalenia pewnych kryteriów umożliwiających ocenę jego realizacji przez potencjalnych arbitrów. Ustalenie takich kryteriów jest szczególnie istotne w odniesieniu do bezstronności, która - jako subiektywny stan umysłu jest niezwykle trudna do wykazania. Przyjęte kryterium musi być przy tym obiektywne, tak aby umożliwiło nie tylko rygorystyczną, ale i praktyczną ${ }^{49}$ analizę istniejącego pomiędzy arbitrem a jedną ze stron postępowania związku. W jednym z orzeczeń Szwajcarskiego Trybunału Federalnego trafnie zatem przyjęto, iż zarzuty stronniczości bądź zależności arbitra oparte wyłącznie na subiektywnym

M. Tomaszewski, Przyczyny wyłaczenia arbitra $w$ świetle prawa polskiego, w: Międzynarodowy i krajowy arbitraż handlowy u progu XXI wieku. Księga pamiątkowa dedykowana doktorowi habilitowanemu Tadeuszowi Szurskiemu, red. A. Tynel, A. Szumański, S. Pieckowski, P. Nowaczyk, J. Poczobut, C.H. Beck, Warszawa 2008, s. 248.

${ }^{48}$ P. Fouchard, E. Gailard, B. Goldman, op.cit., s. 564.

${ }^{49} \mathrm{Z}$ uwagi na wciąż stosunkowo nieliczne grono osób zaangażowanych jako arbitrów w postępowaniach arbitrażowych wydaje się, iż nie jest możliwe przyjęcie poglądu zakładającego absolutną bezstronność i niezależność arbitra. Co więcej, można sądzić, iż przyjęcie tego rodzaju poglądu nie byłoby również wskazane, gdyż niejednokrotnie pozbawiałoby stronę danego postępowania wyboru arbitra posiadającego odpowiednio wysokie kwalifikacje. Tego rodzaju sytuacja mogłaby mieć miejsce w przypadku, gdy przedmiotem postępowania byłby wysoce skomplikowany spór dotyczący wąskiej dziedziny gospodarki. 
odczuciu jednej ze stron sporu zamiast na solidnych podstawach faktycznych, które obiektywnie uzasadniałyby nieufność u rozsądnej osoby trzeciej, powinny być oddalone ${ }^{50}$.

Obecnie najpowszechniejszym kryterium oceny niezależności i bezstronności arbitrów jest, występujący m.in. w Ustawie modelowej UNCITRAL, test „uzasadnionych wątpliwości co do niezależności i bezstronności” (ang. justifiable doubts test). Test ten przyjęło w swoich regulaminach arbitrażowych również wiele stałych sądów polubownych, w tym takie sądy jak Londyński Sąd Arbitrażu Międzynarodowego (LCIA) ${ }^{51}$, Chińska Komisja Arbitrażowa ds. Gospodarki i Handlu Zagranicznego (ang. China International Economic and Trade Arbitration Commission - CIETAC) ${ }^{52}$ czy Instytut Arbitrażowy przy Sztokholmskiej Izbie Handlowej (ang. Arbitration Institute of the Stockholm Chamber of Commerce - SCC) ${ }^{53}$.

Charakterystyczne jednak jest, iż ani Ustawa modelowa UNCITRAL, ani poszczególne regulaminy arbitrażowe nie wyjaśniają, co należy rozumieć przez uzasadnione wątpliwości co do niezależności i bezstronności danego arbitra. Pomocne są tutaj natomiast Wytyczne IBA dotyczące konfliktu interesów w arbitrażu międzynarodowym, które stanowią wyraz powszechnie akceptowanych zasad postępowania arbitrażowego. Zgodnie $z$ Wytycznymi wątpliwości co do niezależności i bezstronności arbitra są uzasadnione, gdy rozsądna i poinformowana osoba trzecia dojdzie do wniosku, iż istnieje prawdopodobieństwo, że na decyzję arbitra mogą mieć wpływ czynniki inne niż istota sprawy przedstawiona przez strony ${ }^{54}$.

Przyjęty przez autorów Wytycznych IBA obiektywny test opiera się na perspektywie właściwie poinformowanej osoby trzeciej zamiast

50 Zob. wyrok Szwajcarskiego Trybunału Federalnego z dnia 11 maja 1992 r. w sprawie D. v. A., "Swiss Arbitration Association Bulletin” 1992, s. 381.

${ }^{51}$ Zob. art. 10.3 Regulaminu arbitrażowego Londyńskiego Sądu Arbitrażu Międzynarodowego.

52 Zob. art. 26 ust. 2 Regulaminu arbitrażowego Chińskiej Komisji Arbitrażowej ds. Gospodarki i Handlu Zagranicznego.

53 Zob. art. 15 (1) Regulaminu arbitrażowego Instytutu Arbitrażowego przy Sztokholmskiej Izbie Handlowej.

54 Zob. Ogólny standard 2(c) Wytycznych IBA dotyczących konfliktu interesów w arbitrażu międzynarodowym z 2004 roku. 
na subiektywnym odczuciu arbitra i powołującej go strony. Wskazania wymaga jednak, iż w odniesieniu do pewnej grupy powiązań między arbitrem a stroną postępowania lub przedmiotem sprawy Wytyczne IBA ustanawiają niewzruszalne domniemanie istnienia uzasadnionych wątpliwości co do niezależności i bezstronności arbitra, które jest oparte na powszechnie uznawanej zasadzie, iż nikt nie może być sędzią we własnej sprawie. Stosownie zatem do Ogólnego standardu 2(d), uzasadnione wątpliwości istnieją w każdym przypadku, w którym strona jest tożsama $z$ arbitrem, gdy arbiter jest pełnomocnikiem strony lub gdy arbiter posiada znaczący interes majątkowy lub osobisty w przedmiotowej sprawie.

Przyjęcie testu „uzasadnionych wątpliwości” wiąże się z pewnymi skutkami proceduralnymi dla stron. Aby móc skutecznie podnieść zarzut stronniczości arbitra, zamiast udowadniać samą jego stronniczość, strona taka powinna w rzeczywistości skupić się na wykazaniu jej przejawów. Stronniczość jest zawsze bowiem trudna, a często w ogóle niemożliwa do udowodnienia ${ }^{55}$. Dokonując oceny bezstronności arbitra, powinno się zatem analizować nie to, czy faktycznie jest on stronniczy, lecz czy okoliczności związane $z$ danym arbitrem dają podstawę do zasadnego uznania go za takiego ${ }^{56}$.

Oprócz testu „uzasadnionych wątpliwości” w praktyce arbitrażu międzynarodowego funkcjonują również inne testy. W orzecznictwie angielskim wykształcono np. test, zgodnie $z$ którym, aby móc uznać arbitra za stronniczego, konieczne jest wykazanie okoliczności wywołujących rzeczywiste niebezpieczeństwo stronniczości danego arbitra (ang. real danger test) ${ }^{57}$. Z kolei w Stanach Zjednoczonych

55 G. Born, International Commercial Arbitration, t. 1, "Kluwer Law International" 2009, s. 605.

${ }^{56}$ G. Bottini, Should Arbitrators Live on Mars? Challenge of Arbitrators in Investment Arbitration, "Suffolk Transnational Law Review" 2008-2009, nr 32, s. 345. Zob. również wyrok Supreme Court of New South Wales w sprawie Grassby v. The Queen z 1989 roku, Commonwealth Law Reports 168.

${ }^{57}$ Zob. wyrok angielskiego Court of Appeal (Civil Division) w sprawie AT\&T Corp. v. Saudi Cable z 15 maja 2000 roku, "2 Lloyd's Law Report 127" 2000; wyrok Quenn's Bench Division (Commercial Court) w sprawie Laker Airways Inc. v. FLS Aerospace z 20 kwietnia 1999 roku, "2 Lloyd's Law Report 45" 1999; wyrok w sprawie Hannam v. Bradford Corporation, “1 WLR 937” 1970. Co ciekawe, test „rzeczywistego niebezpieczeństwa stronniczości” funkcjonuje 
stosowany jest tzw. test „oczywistej stronniczości” (ang. evident partiality). Co istotne, w doktrynie prawniczej trafnie wskazuje się, iż w większości sytuacji zastosowanie któregokolwiek ze wskazanych testów będzie prowadzić do jednakowych rezultatów ${ }^{58}$. Nie można jednak zgodzić się z poglądem niekiedy podnoszonym w orzecznictwie i doktrynie, iż między poszczególnymi testami istnieje niewielka różnica. W praktyce bowiem test „rzeczywistego niebezpieczeństwa” oraz test „oczywistej stronniczości” nakładają na stronę zarzucającą stronniczość większy ciężar dowodowy aniżeli w przypadku zastosowania testu „uzasadnionych wątpliwości”. Zastosowanie tych testów będzie zatem miało istotny wpływ na postępowanie $\mathrm{w}$ przedmiocie oceny niezależności i bezstronności arbitra.

\section{Proceduralne gwarancje niezależności i bezstronności arbitra}

Przestrzeganie przez wszystkich arbitrów nałożonego na nich obowiązku bycia niezależnymi i bezstronnymi zapewnia, po pierwsze, wymóg złożenia przez każdego potencjalnego arbitra oświadczenia o swojej niezależności i bezstronności (ang. duty of disclosure), po drugie natomiast, przyznanie każdej ze stron danego postępowania uprawnienia do złożenia wniosku o wyłączenie danego arbitra, o ile oczywiście zajdą okoliczności budzące uzasadnione wątpliwości co do jego niezależności lub bezstronności ${ }^{59}$.

Obowiązek złożenia oświadczenia o swojej niezależności i bezstronności, w którym dany arbiter musi wyjawić wszystkie okoliczności mogące podważać jego niezależność lub bezstronność, powstaje zasadniczo już w momencie zaproponowania danej osobie objęcia funkcji arbitra. Jakkolwiek złożenie takiego oświadczenia

w angielskim orzecznictwie, mimo iż angielska ustawa - Arbitration Act wyraźnie posługuje się terminem „uzasadnione wątpliwości”.

58 J. Lew, L. Mistelis, S. Kröll, Comparative International Commercial Arbitration, "Kluwer Law International" 2003, s. 305.

$59 \mathrm{~W}$ doktrynie przyjmuje się, iż uprawnienie to stanowi wyjątek od zasady, że raz powołany zespół orzekający sprawuje swoją funkcję aż do momentu wydania wyroku. Zob. ibidem, s. 301. 
zawsze powinno poprzedzać moment powołania, to jednak obowiązek jego złożenia utrzymuje się przez cały okres trwania postępowania. Tylko w takim przypadku oświadczenie to spełni swoją rolę, polegającą na zapewnieniu powołania prawdziwie niezależnego i bezstronnego arbitra.

W doktrynie prawniczej przyjmuje się, iż obowiązek ujawnienia okoliczności mogących wpłynąć na niezależność i bezstronność arbitra dotyczy wyłącznie tych okoliczności, które są istotne ${ }^{60}$. Rodzi to jednak pytanie, które sytuacje można uznać za istotne, a które za nieistotne. Odpowiedź na to pytanie ma duże znaczenie praktyczne. Może się bowiem zdarzyć, iż niepotrzebne ujawnienie pewnych okoliczności, nie dających w rzeczywistości podstaw do uznania arbitra za zależnego lub stronniczego, może skutkować powstaniem błędnego przeświadczenia stron o braku niezależności i bezstronności danego arbitra, niepotrzebnie podważając jednocześnie zaufanie stron do całego procesu ${ }^{61}$.

Mnogość możliwych sytuacji oraz różny stopień ich skomplikowania powoduje jednak, iż nie jest możliwe przytoczenie wyczerpującej i stałej listy okoliczności uznawanych za istotne. Na gruncie Wytycznych IBA zasadniczo przyjmuje się podejście subiektywne, zakładające obowiązek arbitra ujawnienia tych faktów i okoliczności, które mogą prowadzić do powstania wątpliwości co do jego niezależności lub bezstronności w oczach stron. Te same Wytyczne stoją jednak na stanowisku, iż zasada ta nie powinna być stosowana w sposób nieograniczony. Skoro bowiem niektóre sytuacje nigdy nie powinny prowadzić do dyskwalifikacji arbitra w świetle przesłanki obiektywnej, to sytuacje takie nie muszą być ujawnione, niezależnie od punktu widzenia stron ${ }^{62}$. W konsekwencji arbiter powinien wyjawić wszystkie te informacje, które za istotne uznałaby rozsądna osoba trzecia.

$Z$ kolei jeżeli chodzi o wniosek o wyłączenie arbitra, to może on zostać wniesiony przez każdą ze stron i co do zasady w stosunku do każdego arbitra. Pewne ograniczenia w tym zakresie odnoszą się do

\footnotetext{
${ }^{60}$ Ibidem, s. 266.

${ }^{61}$ Objaśnienie do Ogólnego standardu 3 Wytycznych IBA.

${ }^{62}$ Ibidem.
} 
arbitra, którego dana strona sama powołała lub w którego powołaniu uczestniczyła. Powszechnie bowiem się przyjmuje, iż w takiej sytuacji wniosek o wyłączenie tego arbitra strona może wnieść jedynie, gdy istnieją okoliczności, o których strona ta dowiedziała się już po jego powołaniu. Ograniczenie to jest konieczne, gdyż w przeciwnym razie uprawnienie do złożenia wniosku o wyłączenie arbitra mogłoby być wykorzystywane przez strony do utrudniania procesu ${ }^{63}$.

Strona chcąca skorzystać $z$ uprawnienia do wyłączenia arbitra musi wnieść stosowny wniosek niezwłocznie po uzyskaniu informacji stanowiących jego podstawę. Na gruncie Ustawy modelowej UNCITRAL przyjęto rozwiązanie, stosownie do którego, w razie braku odpowiedniego porozumienia stron w tym zakresie, strona powinna złożyć stosowny wniosek w formie pisemnej w terminie $15 \mathrm{dni}$ od dnia, w którym dowiedziała się o ukonstytuowaniu się trybunału arbitrażowego, lub dnia, w którym dowiedziała się o okolicznościach stanowiących podstawę wniosku. Brak wystąpienia w określonym terminie $z$ odpowiednim wnioskiem uznaje się za zrzeczenie się tego uprawnienia przez daną stronę ${ }^{64}$.

\section{Podsumowanie}

Sądownictwo polubowne cechujące się fachowością, elastycznością oraz szybkością jest instytucją o istotnym potencjale i znaczeniu dla uczestników obrotu zarówno krajowego, jak i międzynarodowego. Nie może więc dziwić jego intensywny rozwój w ostatnich latach. Mając jednak na uwadze, iż orzeczenie arbitrażowe stanowi ostateczne i wiążące dla stron danego postępowania rozstrzygnięcie istniejącego pomiędzy nimi sporu, konieczne jest stworzenie pewnych gwarancji praworządności i rzetelności całego procesu. Z tym wiąże się natomiast konieczność nałożenia na wszystkich

${ }^{63}$ Strona mająca świadomość prawdopodobnej przegranej mogłaby bowiem celowo powoływać na arbitra osobę, która niewątpliwie zostałaby uznana za stronniczą lub zależną, tylko po to, aby móc wnieść w odpowiednim czasie wniosek o jej wyłączenie, przedłużając tym samym całe postępowanie.

${ }^{64}$ J. Lew, L. Mistelis, S. Kröll, op.cit., s. 308. 
arbitrów zaangażowanych w postępowaniu arbitrażowym wysokich standardów etycznych, właściwych sędziom sądów powszechnych. Tylko bowiem w ten sposób dalszy rozwój arbitrażu będzie miał solidne fundamenty.

\section{SUMMARY}

\section{Party-appointed arbitrator in International Arbitration}

This paper concentrate on the role played by the party-appointed arbitrators in international arbitration and their neutrality. It is believed that in arbitral proceedings between two parties that are from different countries, party-appointed arbitrators serve as a translators of the legal system of nominating party to the other party and the chairman. Their duty is therefore to explain the other party and the rest of the tribunal the specific provisions of the law and cultural background that follows the party that appointed the them. However, in international arbitration party-appointed arbitrators cannot be seen as a advocates of the nominating party, because all arbitrators must be and remain impartial and independent through the entire arbitration. Moreover, arbitrators unlike the representatives of the parties are adjudicators that share certain core features with judges. Arbitrators, including those appointed unilaterally by the parties, render a final and binding ruling, based upon gathered record and theirs' own judgment. To guarantee arbitrators impartiality and independence, there are under obligation to file formal statements of their impartiality and independence, in which he must reveal any circumstances that might give reasonable doubts as to his impartiality and independence. Furthermore, the parties may file a challenge against an arbitrator on any ground that casts a doubt on his impartiality and independence.

Keywords: arbitral tribunal, arbitration, international arbitration, party-appointed arbitrator. 
